\title{
Mast cells in the human alveolar wall: an electronmicroscopic study
}

\author{
BERNARD FOX, TERENCE B BULL, ABRAHAM GUZ* \\ From the Departments of Histopathology and *Medicine, Charing Cross Hospital Medical School, \\ London W6 8RF
}

SUMMARY Mast cells were identified by electronmicroscopy in the alveolar wall of the lung in 20 subjects (10 normal, 10 abnormal). A quantitative and qualitative study was made of the mast cells. In the normal lung there was an average concentration of 350 mast cells $/ \mathrm{mm}^{2}$ of alveolar wall and in the abnormal $523 / \mathrm{mm}^{2}$. Mast cells occupied approximately $1 \cdot 6-2 \cdot 1 \%$ of the area of the alveolar wall. There was marked variation in the structure of the mast cell granules but no differences between those in the normal and abnormal lungs. There was evidence that constant degranulation of mast cells may be occurring in the lung. The role that alveolar mast cells may play in the vasoconstrictor response to alveolar hypoxia is discussed. It is suggested that the tachypnoea present in asthma may partly be due to release of mediators from sensitised mast cells within the alveolar wall.

It has been generally thought that mast cells in the human lung are found deep to the bronchial mucous membrane ${ }^{12}$ and also around blood vessels particularly venules deep in connective tissue. ${ }^{3}$

During the course of routine electronmicroscopic study of human lungs we were suprised to see mast cells within the alveolar wall. We therefore studied systematically by electronmicroscopy both qualitatively and quantitatively the distribution of mast cells within alveoli in normal and abnormal human lung tissue.

\section{Material and methods}

Lung tissue was obtained by thoracotomy from 20 patients of which lung disease was present in 10 (Table 1). The assessment of disease in the lung was made by examining paraffin sections of lung tissue adjacent to the areas from which the sections for electronmicroscopy were taken. A piece of lung tissue (about $1 \mathrm{~cm} \times 1 \mathrm{~cm} \times 0.5 \mathrm{~cm}$ ) was taken immediately after the specimen was removed, and placed in Karnovsky fixative at $4^{\circ} \mathrm{C}$ : after one hour the tissue was cut into pieces approximately $2 \mathrm{~mm}$ $\times 2 \mathrm{~mm} \times 1 \mathrm{~mm}$ and allowed to fix for a further three hours. The specimens were washed overnight in cacodylate-sucrose buffer at $4^{\circ} \mathrm{C}$, then postfixed in $1 \%$ osmium tetroxide for one hour at $4^{\circ} \mathrm{C}$. This was

Accepted for publication 6 May 1981 followed by washing in distilled water for five minutes and block staining in $2 \%$ aqueous uranyl acetate for one hour. The tissue was dehydrated to absolute alcohol and placed in two changes of epoxypropane for $15 \mathrm{~min}$ each, and then in warmed $\left(60^{\circ} \mathrm{C}\right)$ Araldite for one hour. The tissue was then embedded in fresh Araldite at $60^{\circ} \mathrm{C}$ for at least $48 \mathrm{~h}$. Sections were cut at $2 \mu \mathrm{m}$, stained with toluidine blue, and areas showing alveolar walls were selected for ultrathin sections. These were then cut with gold interference colour mounted on G200 HT copper grids and contrasted with $2 \%$ uranyl acetate and lead citrate and examined in a Philips EM 201.

\section{CRITERIA FOR IDENTIFICATION OF MAST}

CELLS

We have identified mast cells at electronmicroscopy only. The features used to establish identity were (a) the presence of membrane bound intracytoplasmic granules $600-800 \mathrm{~nm}$ in diameter (b) the characteristic intragranular inclusions of various forms and (c) the presence of long filiform microvilli on the surface 4 (Fig. 1). These criteria help to distinguish mast cells from basophils. Basophils do contain intracytoplasmic granules but these are smaller than those found in mast cells and the basic intragranular inclusion is finely granular, whereas those of the mast cells are variable in structure with many scrolls. The surface of the basophil has cytoplasmic protrusions which are much wider and 1333 
Table 1 Patient diagnoses and pathology of lung tissue

\begin{tabular}{|c|c|c|c|c|c|}
\hline Case & Age/sex & Diagnosis & Allergic history & Origin of tissue & $\begin{array}{l}\text { Light } \\
\text { microscopy* }\end{array}$ \\
\hline \multicolumn{6}{|c|}{ Normal } \\
\hline 1 & $59 \mathrm{~F}$ & Carcinoma of lung & - & Lobectomy & Normal \\
\hline 2 & $63 \mathrm{M}$ & Carcinoma of bronchus & - & Lobectomy & Normal \\
\hline 3 & $69 \mathrm{M}$ & Carcinoma of lung & - & Pneumonectomy & Normal \\
\hline 4 & $56 \mathrm{M}$ & Bronchiectasis & - & Lobectomy & Normal \\
\hline 5 & $54 \mathrm{~F}$ & Carcinoma of bronchus & - & Lobectomy & Normal \\
\hline 6 & $63 \mathrm{M}$ & Carcinoma of bronchus & - & Pneumonectomy & Normal \\
\hline 7 & $71 \mathrm{~F}$ & Carcinoma of lung & $\therefore$ & Lobectomy & Normal \\
\hline 8 & $62 \mathrm{~F}$ & Carcinoma of bronchus & - & Lobectomy & Normal \\
\hline 9 & $72 \mathrm{~F}$ & Carcinoma of lung & - & Lobectomy & Normal \\
\hline 10 & $63 \mathrm{M}$ & Carcinoma of bronchus & - & Pneumonectomy & Normal \\
\hline \multicolumn{6}{|c|}{ Abnormal } \\
\hline 11 & $47 \mathrm{~F}$ & Interstitial pulmonary fibrosis & - & Biopsy & Fibrosis \\
\hline 12 & $53 \mathrm{M}$ & $\begin{array}{l}\text { Carcinoma of bronchus } \\
\text { Silicosis }\end{array}$ & - & Lobectomy & Fibrosis \\
\hline 13 & $51 \mathrm{M}$ & $\begin{array}{l}\text { Interstitial pulmonary fibrosis } \\
\text { Rheumatoid arthritis }\end{array}$ & - & Biopsy & Fibrosis \\
\hline 14 & $37 \mathrm{M}$ & $\begin{array}{l}\text { Sarcoidosis } \\
\text { Interstitial pulmonary fibrosis }\end{array}$ & - & Biopsy & Sarcoidosis \\
\hline 15 & $69 \mathrm{M}$ & $\begin{array}{l}\text { Carcinoma of bronchus } \\
\text { Interstitial pulmonary fibrosis }\end{array}$ & - & Lobectomy & Normal \\
\hline 16 & $47 \mathrm{M}$ & $\begin{array}{l}\text { Bronchiectasis } \\
\text { Interstitial pulmonary fibrosis }\end{array}$ & - & Lobectomy & Normal \\
\hline 17 & $74 \mathrm{~F}$ & $\begin{array}{l}\text { Carcinoma of bronchus } \\
\text { Interstitial pulmonary fibrosis } \\
\text { Sarcoidosis }\end{array}$ & - & Lobectomy & Normal \\
\hline 18 & $67 \mathrm{M}$ & $\begin{array}{l}\text { Bronchiolitis obliterans } \\
\text { Inte-stitial pulmonary fibrosis }\end{array}$ & - & Biopsy & Normal \\
\hline 19 & $30 \mathrm{~F}$ & $\begin{array}{l}\text { Bronchiectasis } \\
\text { Interstitial pulmonary fibrosis }\end{array}$ & - & Lobectomy & Normal \\
\hline 20 & $77 \mathrm{M}$ & I aterstitial pulmonary fibrosis & - & Biopsy & Normal \\
\hline
\end{tabular}

*Assessment of lung tissue by examination of toluidine blue-stained sections of blocks examined by electronmicroscopy.

shorter than those of the mast cell. Another distinguishing feature is that the nucleus of basophils is usually multilobular whereas the mast cell nucleus is unilobular. $^{5}$

\section{ASSESSMENT OF NUMBER OF MAST CELLS}

AND AREA OF ALVEOLAR WALL

At the start of each film a diffraction grating replica of 2160 lines/mm was photographed at a negative magnification of approximately 935 times; the same magnification was used for examination of the alveolar wall. Two diagonally opposite corners of each square of the grid which contained alveolar wall only, were photographed and approximately 34 negatives were taken from each specimen. Image analysis equipment (Cambridge Electronic Design Ltd, Cambridge) was used for measurement of the areas of alveolar wall and mast cells. For the alveolar wall the negatives were projected by a photographic enlarger to a magnification of about $\times 6000$ on to the magnetised tablet of the image analyser and the outlines of the alveolar wall mapped out with a cross hair cursor. The image analyser was calibrated with the image of the cross grating so that the areas of the alveolar wall (in $\mu \mathrm{m}^{2}$ ) were read off directly from the analyser. The number of mast cells or parts of mast cells seen within the area of alveolar wall were counted. To estimate the areas of mast cells, prints were made at a final magnification of 9340 of each mast cell in which the whole cell and nucleus were present and the area of the cell was measured using the technique described for the alveolar wall.

\section{ASSESSMENT OF TYPES OF MAST CELL GRANULES}

Five mast cells from each case except case 8 (in which only one cell was found) were photographed at a final magnification of 43660 . The prints of each mast cell were overlapped so that the number of different types of granules in the mast cell could be counted. The granules were classified into four categories-"scrolls" (S) "reticular" (R) "combined"- that is, mixture of scrolls and reticular (C) and mainly empty vesicles (E) (Fig. 2).

\section{STATISTICAL ANALYSIS}

Results on tissue from normal and abnormal lung were compared using unpaired $t$ test. 


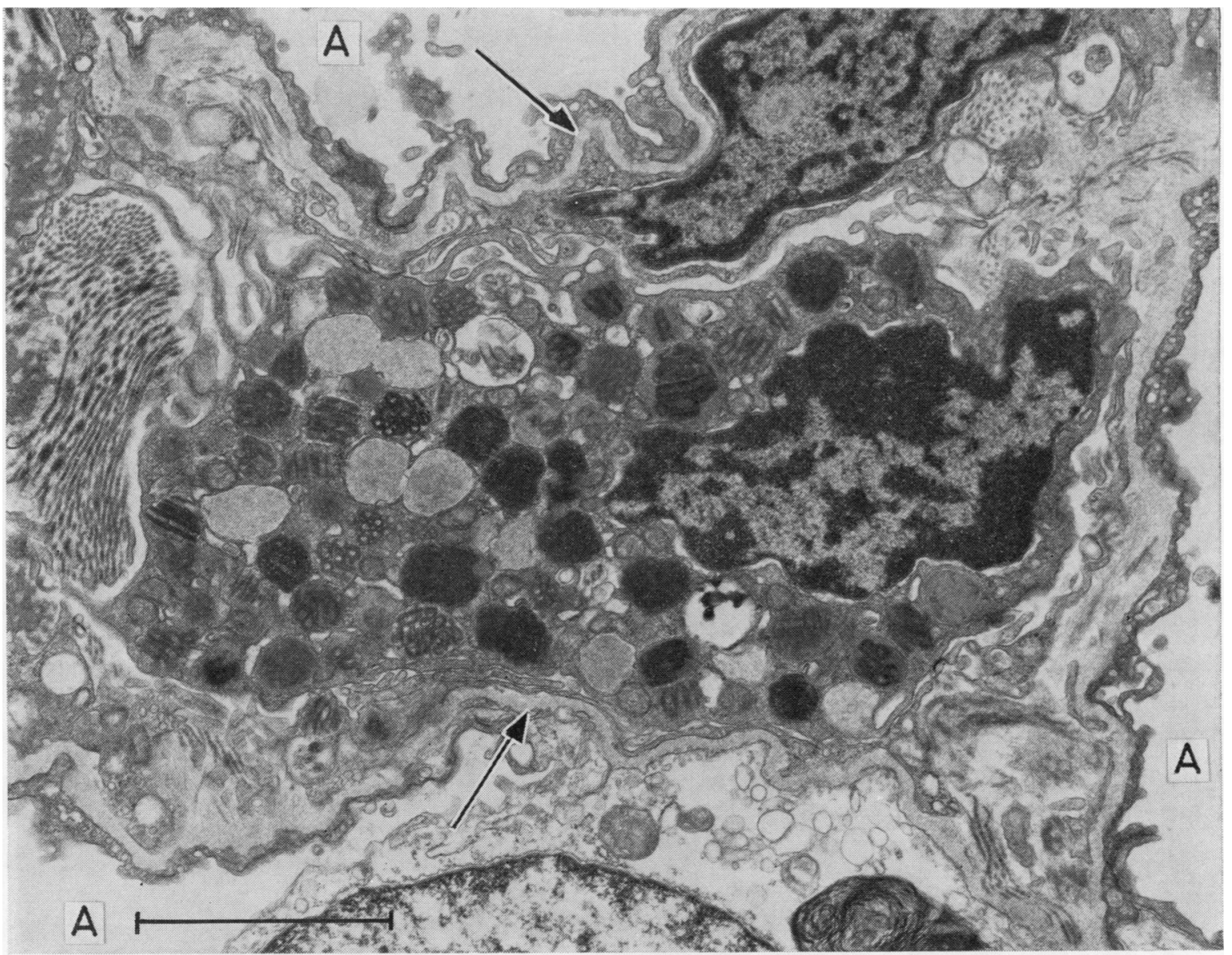

Fig. 1 Mast cell within the alveolar wall, close to the air space $(A)$ and the alveolar wall basement membrane (arrow). Part of the nucleus and cytoplasm of a type II pneumonocyte at the bottom of the figure. Bar mark: $2 \mu \mathrm{m}$.

\section{Results}

Mast cells were found within the alveolar wall in 19 out of the 20 cases studied (Table 2). A typical finding was the presence of a mast cell within the interstitial tissue less than $1 \mu \mathrm{m}$ from the air surface (Figs 1 and 3 ) and the proximity of the filiform microvillous processes to the basement membrane of the alveolar wall is clearly seen. A mast cell was seen apparently within the alveolar surface (Fig. 4) and occasional mast cells were found free within the alveolar air space (Fig. 5); these cells were not quantified.

The mean area of the alveolar wall surveyed was of the order of $12-1300 \mu \mathrm{m}^{2}$ in both normal and abnormal lungs and the number of mast cells found in the area was an average of 4.2 in the normal and 6.3 in the abnormal lungs. Full details are given in Table 2.

The normal lungs showed an average concentration of 350 mast cells $/ \mathrm{mm}^{2}$ of alveolar wall whereas the abnormal lungs showed an average of $523 / \mathrm{mm}^{2}$ of alveolar wall. These groups were not significantly different. Table 2 also shows that $1 \cdot 6-2 \cdot 1 \%$ of the area of the alveolar wall consists of mast cells.

The type of inclusions within the granules are shown in Table 3. The total number of granules counted ranged from 9-100 with an average of 39.6. The Table expresses the type of granule found as a percentage of the total number. There was greater variation in the distribution of the different types of granules but no significant differences were found in 

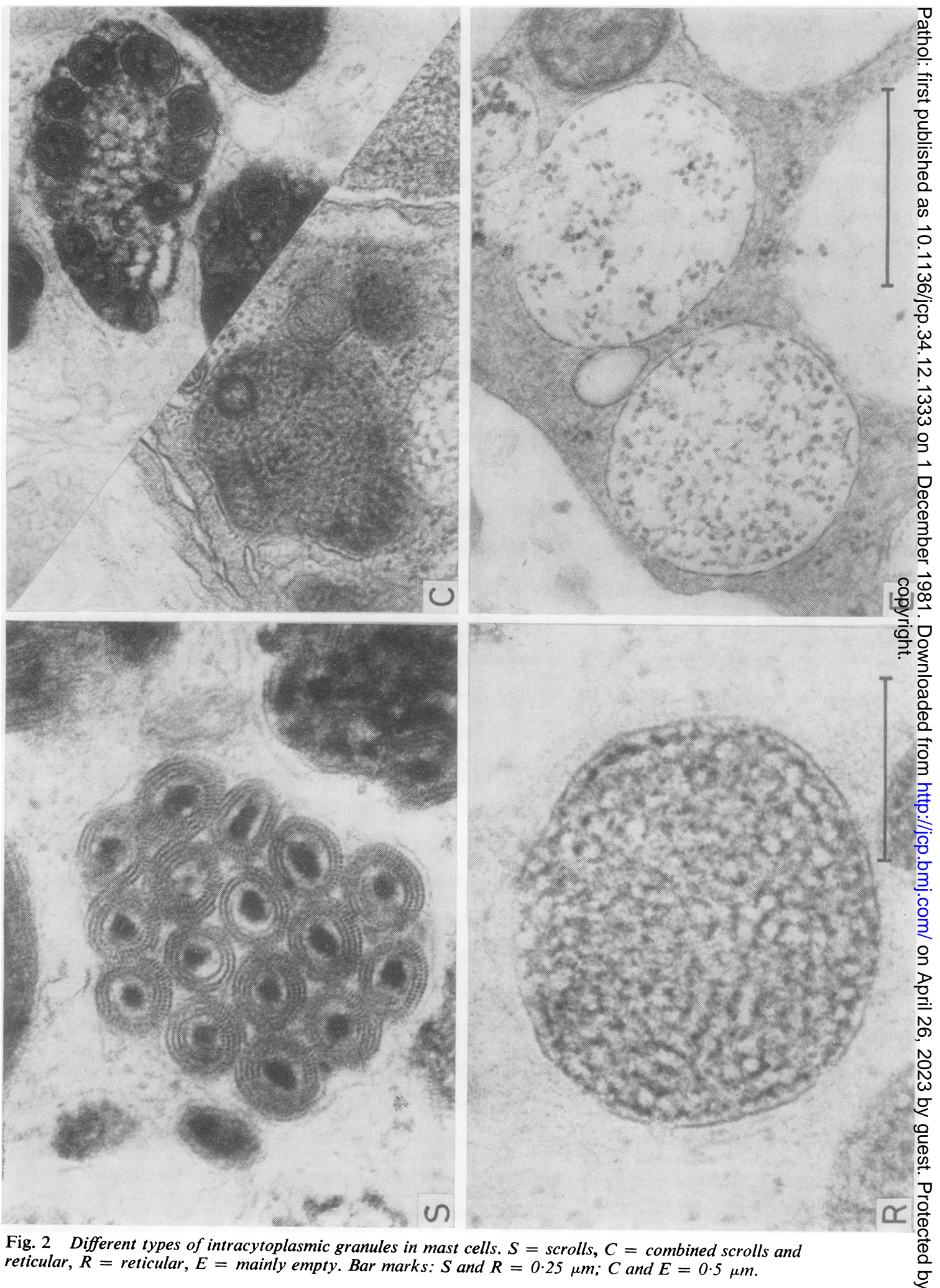

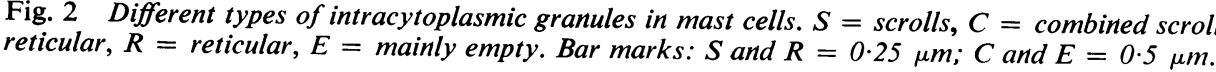


Table 2 Numbers and areas of mast cells in alveolar wall

\begin{tabular}{|c|c|c|c|c|c|c|}
\hline Case & $\begin{array}{l}\text { Area of alveolar wal! } \\
\left(u \mathrm{~m}^{2}\right)\end{array}$ & No of mast cells & $\begin{array}{l}\text { No of mast cells/ } \\
\mathrm{mm}^{2} \text { alveolar wall }\end{array}$ & $\begin{array}{l}\text { Mean area of mast cells } \\
\left(\mu m^{2}\right)\end{array}$ & $n$ & $\frac{\text { Area of mast cells }}{\text { Area of alveolar wall }} \%$ \\
\hline \multicolumn{7}{|c|}{ Normal } \\
\hline $\begin{array}{r}1 \\
2 \\
3 \\
4 \\
5 \\
6 \\
7 \\
8 \\
9 \\
10\end{array}$ & $\begin{array}{rl}7 & 674 \\
10113 \\
11650 \\
10428 \\
13699 \\
14805 \\
14029 \\
9758 \\
18108 \\
11627 \\
\text { Mean = 12 } 189 \\
\text { SD }=3016\end{array}$ & $\begin{array}{l}2 \\
7 \\
2 \\
6 \\
8 \\
5 \\
6 \\
0 \\
2 \\
4 \\
\text { Mean }=4 \cdot 2 \\
\text { SD }=2 \cdot 6\end{array}$ & $\begin{array}{l}260 \\
692 \\
172 \\
575 \\
584 \\
338 \\
427 \\
- \\
110 \\
344 \\
\text { Mean }=350 \cdot 2 \\
\text { SD }=223 \cdot 2\end{array}$ & $\begin{array}{l}\overrightarrow{34} \cdot 1 \\
\overrightarrow{20} \cdot 5 \\
35,3 \\
28 \cdot 4 \\
37 \cdot 2 \\
\overline{-} \\
39 \cdot 1 \\
\text { Mean }=32 \cdot 4 \\
\text { SD }=6.9\end{array}$ & $\begin{array}{l}2 \\
3 \\
4 \\
3 \\
3\end{array}$ & $\begin{array}{l}\overline{2.36} \\
\overline{1} \cdot 18 \\
2.06 \\
0.96 \\
1.59 \\
- \\
\overline{1.35} \\
\text { Mean }=1.6 \\
\text { SD }=0.5\end{array}$ \\
\hline \multicolumn{7}{|c|}{ Abnormal } \\
\hline $\begin{array}{l}11 \\
12 \\
13 \\
14 \\
15 \\
16 \\
17 \\
18 \\
19 \\
20\end{array}$ & $\begin{array}{r}12818 \\
8185 \\
12300 \\
13750 \\
16304 \\
10017 \\
6145 \\
14619 \\
15767 \\
16203 \\
\text { Mean = } 12611 \\
\text { SD = 3498 }\end{array}$ & $\begin{array}{l}11 \\
6 \\
6 \\
5 \\
6 \\
4 \\
4 \\
8 \\
11 \\
2 \\
\text { Mean }=6.3 \\
\text { SD }=2.9\end{array}$ & $\begin{array}{l}858 \\
733 \\
488 \\
364 \\
368 \\
399 \\
650 \\
547 \\
698 \\
123 \\
\text { Mean }=522 \cdot 8 \\
\text { SD }=218 \cdot 5\end{array}$ & $\begin{array}{l}46 \cdot 15 \\
30 \cdot 5 \\
28 \cdot 9 \\
41 \cdot 8 \\
41 \cdot 2 \\
50 \cdot 5 \\
29 \cdot 3 \\
57 \cdot 4 \\
43 \cdot 95 \\
50 \cdot 9 \\
\text { Mean }=42 \cdot 1 \\
\text { SD }=9 \cdot 9\end{array}$ & $\begin{array}{l}4 \\
2 \\
2 \\
1 \\
1 \\
2 \\
3 \\
4 \\
7 \\
1\end{array}$ & $\begin{array}{l}3.96 \\
2.24 \\
1.41 \\
1 \cdot 52 \\
1.5 \\
2.02 \\
1.91 \\
3.14 \\
3.06 \\
0.63 \\
\text { Mean }=2.1 \\
\text { SD }=1.0\end{array}$ \\
\hline
\end{tabular}

the distribution of any particular granular type as between normal and abnormal cases.

\section{ASSESSMENT OF NORMALITY OF LUNG}

Since all lung tissue was removed for a pathological process (Table 1) the assessment of changes in the tissue submitted for electronmicroscopy was made by examination of the toluidine blue sections cut at $2 \mu \mathrm{m}$. In only four examples of the 10 classified as abnormal on clinical and histological grounds, was the tissue thought to be abnormal on electronmicroscopy.

\section{Discussion}

The most surprising finding of our study is the relatively large numbers of mast cells present within the alveolar wall in all but one specimen examined. The finding that as much as $2 \%$ of the alveolar wall in man is occupied by mast cells must prompt the question as to why this observation has not been made previously. We think that the answer is that previous authors have identified mast cells by the traditional metachromatic staining techniques. ${ }^{8}$ It is of interest that using these techniques, mast cells were described in human lungs ${ }^{3}$ mainly in perivascular tissue but without particular localisation to the alveolar wall. If metachromatic staining tech- niques are relied on as the sole means of identification, the degranulated and partly degranulated mast cells may be missed. ${ }^{6}$ Nevertheless during the course of our study Kawanami et al $^{7}$ also commented on the presence of mast cells in the alveolar wall of man identified at light microscopy with toluidine blue-stained sections; the numbers reported were much lower than in the present study. One of the possible reasons for this discrepancy is that we quantified mast cells in relation to the area of the alveolar wall, whereas Kawanami et $\mathrm{al}^{7}$ related mast cells to the area of lung parenchyma, which of course includes large amounts of alveolar air. We are more concerned, however, over the probability of mast cells being missed because electronmicroscopy was not used. Our concern at this possibility is heightened by the fact that the thickness of the sections used by Kawanami et al $^{7}$ was much greater than in our study (500 nm compared with $60-80 \mathrm{~nm}$ ) and this should have served to increase the apparent concentration of mast cells seen in their study.

The most significant aspect of our study is that our data suggest that there is no difference between mast cell content between normal and abnormal alveolar wall. Here there is a major disagreement with Kawanami et $a l^{7}$ who found very few mast cells in normal lungs but a twentyfold increase in lungs from various forms of interstitial pulmonary fibrosis and 


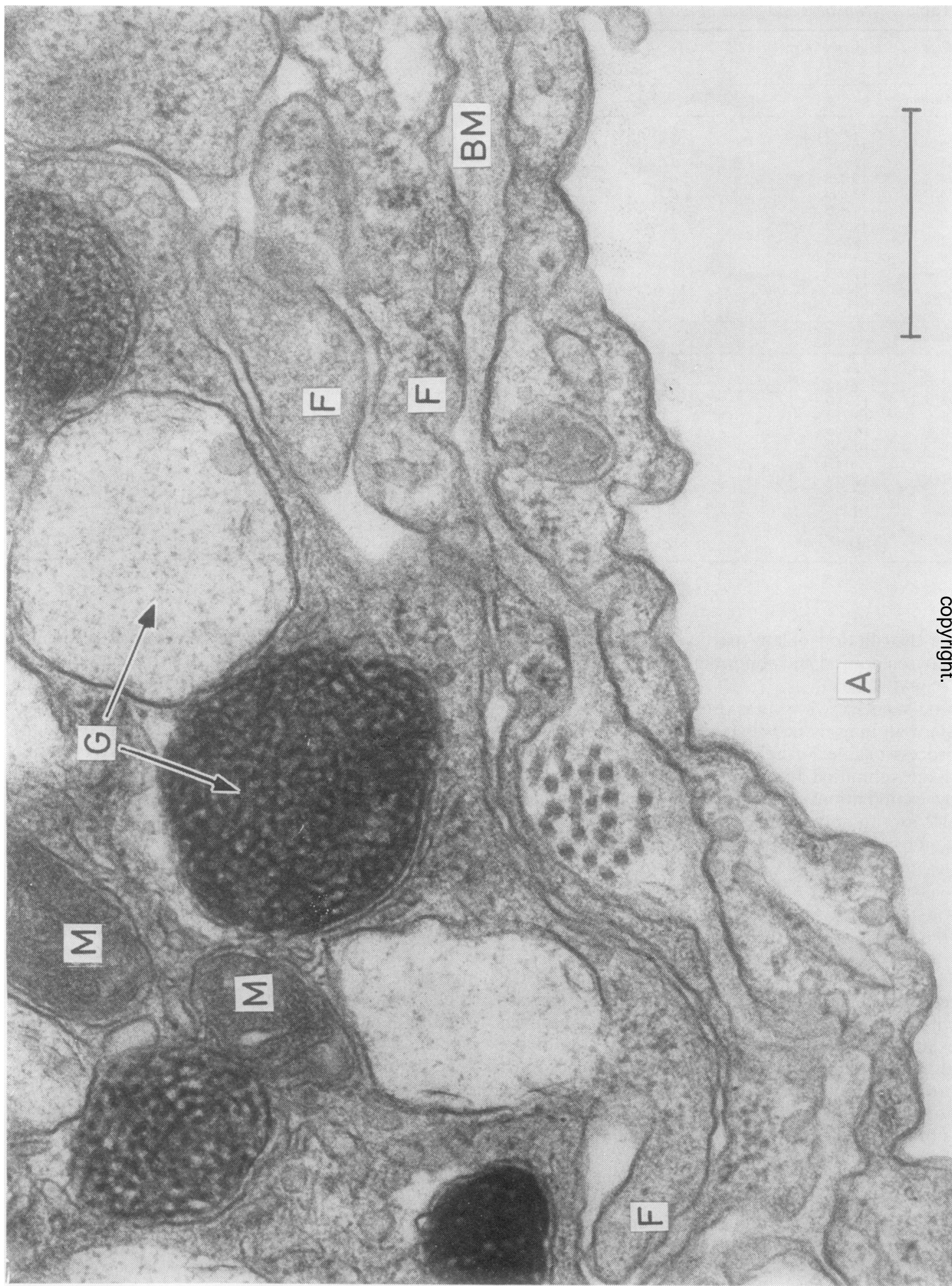

Fig. 3 The relationship of surface of mast cell to the basement membrane of the alveolar wall $(B M)$ and the air. space $A . F=$ filiform processes of mast cell, $M=$ mitochondria, $G=$ granules of mast cell. Bar mark: $0 \cdot 5 \mu \mathrm{m}$. 


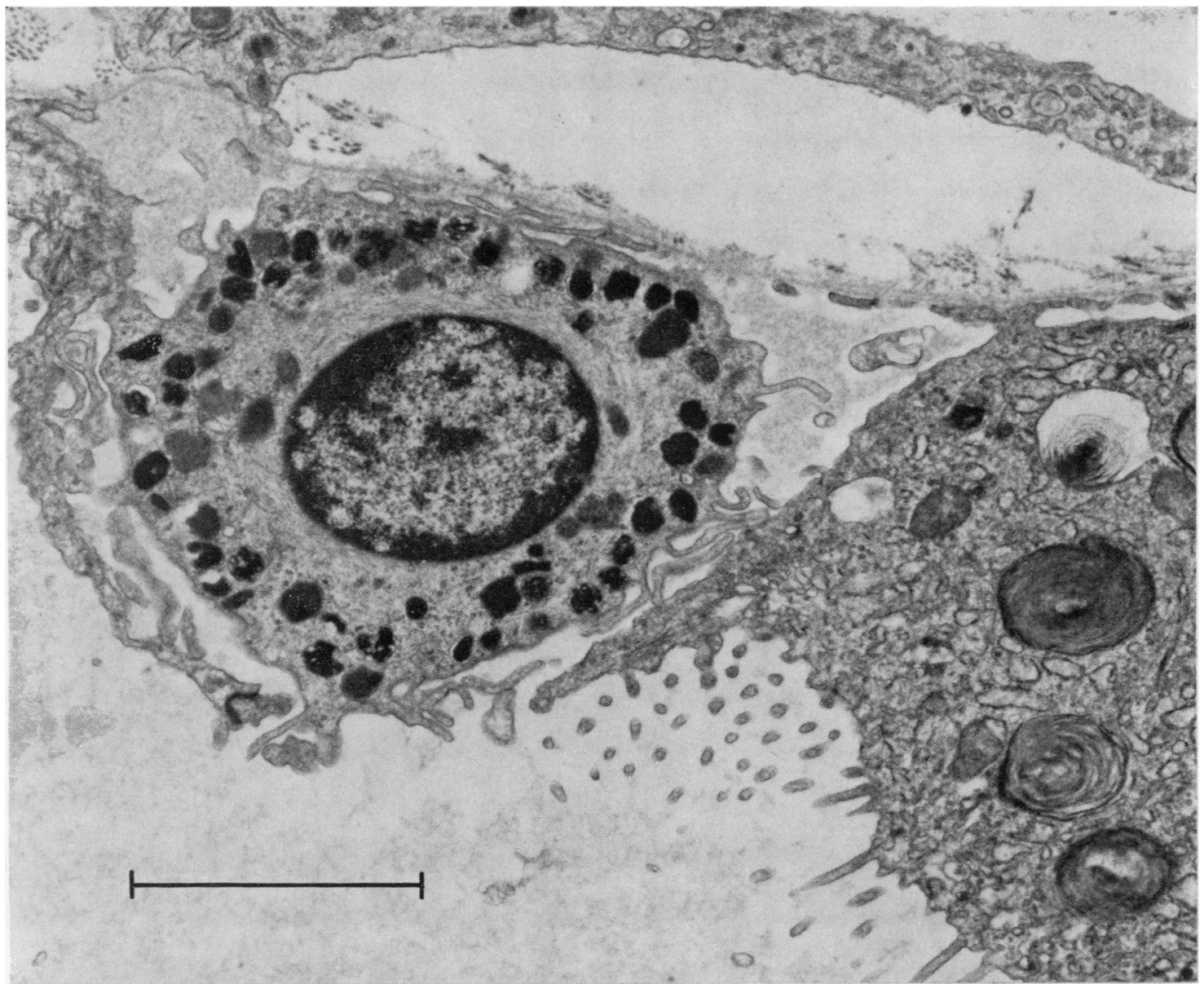

Fig. 4 Mast cell protruding through the alveolar wall, partly covered by cytoplasm of pneumonocyte type I on the left and of type II cell on the right. There is oedema of interstitial tissue beneath the mast cell. Bar mark: $3 \mu \mathrm{m}$.

other diseases. The evidence of "normality" in the present study was based on the examination of haemalum and eosin stained sections taken from tissue adjacent to that which was submitted to electromicroscopy. In addition the toluidine blue stained sections of the blocks used for electronmicroscopy were also critically examined for normality. This procedure in practice brought out a discrepancy demonstrated in Table 2 , where the toluidine sections were sometimes found to be normal even in the lungs, where unequivocal pathology was seen in the haemalum and eosin sections from adjacent tissue. This highlights the well-known problem of sampling error in electronmicroscopy, when dealing with a non-uniform disease process. Since we have submitted to electronmicroscopy only four examples (cases 11-14) with unequivocal disease of the lung we are in no position to comment on any additional pathogenic role of mast cells.

Our findings on the granules and their morphological structures are in keeping with those in published reports. ${ }^{49}$ It is generally accepted that during the process of degranulation and presumed release of mediators the sequence of structural changes is from "scrolls" to "combined" to "reticular" to "empty". 47 If this sequence is true for the lung of man then our data suggest that a constant degranulation is taking place in the normal lung. There is no evidence whatsoever that the degranulation process is in any way more marked in the pathological tissue that we have examined. Here again we would have to disagree with the electronmicroscopic findings of the granular content of mast 


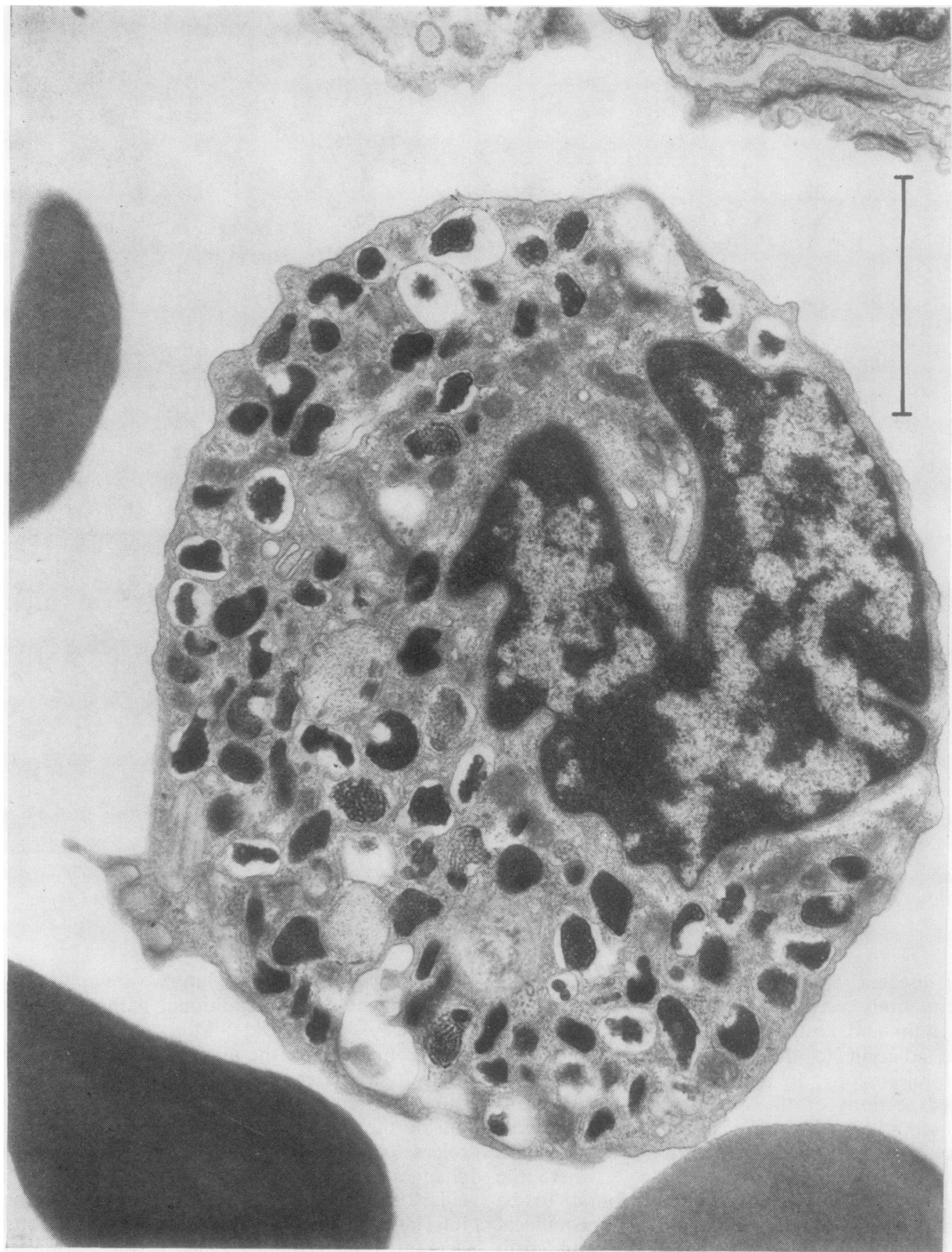

Fig. 5 Mast cell in the air space which is contaminated by red cells. The alveolar wall is at the top. Bar mark: $2 \mu \mathrm{m}$. 
cells as reported by Kawanami et $a l,{ }^{7}$ who suggested that degranulation was more common in cases of pulmonary fibrosis and other pathological changes in the lung. In their study there was no statement of any pathological changes in the tissue submitted for electronmicroscopy.

It is interesting to speculate on the function of mast cells in the alveolar wall. An obvious candidate would be the control of the pulmonary vascular resistance and perhaps more particularly the provision of mediators for the pulmonary vascular response to alveolar hypoxia. It is of the greatest interest that Hauge and Staub ${ }^{10}$ showed that hypoxic vasoconstriction in the cat lung could be

Table 3 Numbers and types of granules in mast cells in alveolar wall

\begin{tabular}{lllll}
$\begin{array}{l}\text { Total No } \\
\text { granules }\end{array}$ & $\%$ type & granules & & \\
\cline { 2 - 5 } & Scroll & $\begin{array}{l}\text { Scrolly } \\
\text { reticular }\end{array}$ & Reticular & Empty
\end{tabular}

\begin{tabular}{|c|c|c|c|c|c|}
\hline \multicolumn{6}{|l|}{ Normal } \\
\hline \multirow[t]{5}{*}{ Case 1} & 18 & - & 50 & 50 & - \\
\hline & 21 & - & - & 43 & 57 \\
\hline & 16 & - & - & 69 & 31 \\
\hline & 18 & - & 6 & 89 & 5 \\
\hline & 19 & - & 42 & 42 & 16 \\
\hline \multirow[t]{5}{*}{ Case 2} & 51 & 61 & 35 & 4 & - \\
\hline & 28 & 18 & 46 & 36 & - \\
\hline & 21 & 52 & 29 & 19 & - \\
\hline & 37 & 60 & 40 & - & - \\
\hline & 13 & 31 & 69 & - & - \\
\hline \multirow[t]{5}{*}{ Case 3} & 79 & - & 10 & 80 & 10 \\
\hline & 57 & - & 22 & 74 & 4 \\
\hline & 21 & 29 & 14 & 57 & - \\
\hline & 28 & 44 & 30 & 21 & 5 \\
\hline & 63 & - & 37 & 63 & - \\
\hline \multirow[t]{5}{*}{ Case 4} & 43 & 74 & 5 & 16 & 5 \\
\hline & 19 & 42 & 21 & 11 & 26 \\
\hline & 11 & 46 & 45 & 9 & - \\
\hline & 53 & 89 & 4 & 2 & 5 \\
\hline & 63 & 84 & 16 & - & - \\
\hline \multirow[t]{5}{*}{ Case 5} & 23 & 22 & 30 & 35 & 13 \\
\hline & 23 & - & 18 & 78 & 4 \\
\hline & 35 & - & 17 & 83 & - \\
\hline & 31 & - & 6 & 94 & - \\
\hline & 46 & 2 & 37 & 61 & - \\
\hline \multirow[t]{5}{*}{ Case 6} & 38 & 100 & - & - & - \\
\hline & 30 & 80 & 10 & 10 & - \\
\hline & 42 & 95 & 5 & - & - \\
\hline & 22 & 32 & 27 & 41 & - \\
\hline & 53 & 98 & 2 & - & - \\
\hline \multirow[t]{5}{*}{ Case 7} & 33 & 24 & 70 & 6 & - \\
\hline & 63 & 68 & 24 & 8 & - \\
\hline & 49 & 4 & 59 & 37 & - \\
\hline & 46 & 78 & 13 & 9 & - \\
\hline & 27 & 37 & 59 & 4 & - \\
\hline Case 8 & 25 & 80 & 12 & 8 & - \\
\hline \multirow[t]{5}{*}{ Case 9} & 16 & 25 & 38 & 37 & - \\
\hline & 27 & 7 & 41 & 44 & 8 \\
\hline & 24 & 17 & 54 & 17 & 12 \\
\hline & 16 & 44 & 31 & 25 & - \\
\hline & 29 & - & 10 & 90 & - \\
\hline \multirow[t]{5}{*}{ Case 10} & 37 & 11 & 29 & 59 & 1 \\
\hline & 9 & - & 56 & 44 & - \\
\hline & 51 & - & 96 & 4 & - \\
\hline & 68 & - & - & 98 & 2 \\
\hline & 67 & 3 & 13 & 84 & - \\
\hline
\end{tabular}

\begin{tabular}{|c|c|c|c|c|c|}
\hline \multicolumn{6}{|c|}{ Abnormal } \\
\hline \multirow[t]{5}{*}{ Case 11} & 43 & 98 & - & 2 & - \\
\hline & 27 & 74 & 26 & - & 一 \\
\hline & 61 & 34 & 6 & 50 & 10 \\
\hline & 100 & 2 & 13 & 56 & 29 \\
\hline & 26 & 23 & - & 62 & 15 \\
\hline \multirow[t]{5}{*}{ Case 12} & 19 & 16 & - & 84 & 一 \\
\hline & 35 & - & 3 & 97 & - \\
\hline & 12 & 34 & 33 & 33 & - \\
\hline & 44 & 5 & 36 & 59 & - \\
\hline & 15 & 100 & - & - & - \\
\hline \multirow[t]{5}{*}{ Case 13} & 58 & 2 & 12 & 86 & - \\
\hline & 28 & 78 & - & 22 & - \\
\hline & 35 & 94 & 6 & - & - \\
\hline & 70 & - & 7 & 74 & 19 \\
\hline & 80 & - & 15 & 85 & $\overline{-1}$ \\
\hline \multirow[t]{5}{*}{ Case 14} & 44 & - & - & 70 & 30 \\
\hline & 18 & - & - & 100 & - \\
\hline & 61 & - & - & 100 & 一 \\
\hline & 51 & 4 & 35 & 57 & 4 \\
\hline & 61 & - & 13 & 67 & 20 \\
\hline \multirow[t]{5}{*}{ Case 15} & 80 & 20 & 45 & 35 & - \\
\hline & 44 & 39 & 41 & 18 & 2 \\
\hline & 37 & 3 & 5 & 92 & - \\
\hline & 15 & - & 27 & 60 & 13 \\
\hline & 85 & 4 & 13 & 76 & 7 \\
\hline \multirow[t]{5}{*}{ Case 16} & 39 & 46 & 51 & 3 & - \\
\hline & 40 & 93 & 7 & - & - \\
\hline & 28 & 14 & 39 & 22 & 25 \\
\hline & 40 & 53 & 37 & 10 & 一 \\
\hline & 47 & 9 & 9 & 18 & 64 \\
\hline \multirow[t]{5}{*}{ Case 17} & 40 & - & 95 & - & 5 \\
\hline & 48 & 33 & 67 & - & - \\
\hline & 71 & 32 & 68 & - & - \\
\hline & 18 & - & 100 & - & - \\
\hline & 38 & 21 & 47 & 32 & - \\
\hline \multirow[t]{5}{*}{ Case 18} & 39 & 67 & 18 & 10 & 5 \\
\hline & 18 & - & - & 83 & 17 \\
\hline & 54 & 85 & 8 & 7 & 一 \\
\hline & 38 & - & 37 & 63 & - \\
\hline & 34 & 62 & 26 & 12 & - \\
\hline \multirow[t]{5}{*}{ Case 19} & 37 & 22 & 62 & 16 & - \\
\hline & 51 & 90 & 10 & - & 一 \\
\hline & 39 & 46 & 41 & 13 & - \\
\hline & 66 & 68 & 23 & 9 & 一 \\
\hline & 56 & 57 & 43 & - & - \\
\hline \multirow[t]{5}{*}{ Case 20} & 48 & - & 13 & 81 & 6 \\
\hline & 45 & 4 & 69 & 18 & 9 \\
\hline & 42 & - & - & 55 & 45 \\
\hline & 21 & 14 & 81 & 5 & 一 \\
\hline & 45 & 2 & 45 & 51 & 2 \\
\hline
\end{tabular}

prevented by prior use of a histamine releasing agent 48/80. Haas and Bergofsky ${ }^{11}$ have elaborated on the idea that pulmonary mast cells are degranulated in vivo during alveolar hypoxia at least in the rat; however more recently Bergofsky ${ }^{12}$ in reviewing this field, was of the opinion that the case for histamine as the mediator for hypoxic vasoconstriction in the lungs required substantial reservations, particularly since there is a considerable controversy over the ability to inhibit the hypoxic response in the lung by histamine antagonists.1012-14 It should not be forgotten, however, that mast cells release 
other chemical mediators some of which are known vasoconstrictors. Nevertheless it should be remembered that mast cells described in this paper are close to capillaries and not to small arteries, and the evidence available suggests that the principal site of pulmonary vascular resistance sensitive to alveolar hypoxia lies in arteries $<200 \mu \mathrm{m}$ in diameter. ${ }^{15}$

The important pathophysiological consequence of the localisation of sensitised mast cells so close to the air surface is that mediator release could occur within the alveolar wall as the result of inhalation of the appropriate antigen. The immediate hypersensitivity reaction could therefore also occur within the alveolar wall. It is conceivable that the typical tachypnoea of asthma originates from the stimulation of the lung $J$ receptors ${ }^{16} 17$ by chemicals released from these mast cells.

We would like to thank Professor JC Sloper, Department of Experimental Pathology for use of the image analysis equipment.

\section{References}

${ }^{1}$ Orange RP. Immunopharmacological aspects of bronchial asthma. Clin Allergy 1973;3 suppl:521-37.

2 Patterson R, Suszko IM. Primate respiratory mast cells. $J$ Immunol 1971;106:1274-83.

${ }^{3}$ Selye H. The mast cell. Washington: Butterworths, 1965.

4 Trotter CM, Orr TSC. A fine structure study of some cellular components in allergic reactions. Clin Allergy 1973;3:411-25.

5 Ts'ao C-h, Patterson R, McKenna JM, Suszko IM. Ultrastructural identification of mast cells obtained from human bronchial lumens. $J$ Allergy Clin Immunol 1970;59:320-6.
- Salvato G. Some histological changes in chronic bronchitis and asthma. Thorax 1968;23:168-72.

${ }^{7}$ Kawanami O, Ferrans VJ, Fulmer JD, Crystal RG. Ultrastructure of pulmonary mast cells in patients with fibrotic lung disorders. Lab Invest 1979;40:717-34.

${ }^{8}$ Drury RAB, Wallington EA. Carleton's histological technique 4th ed. London: Oxford University Press, 1976:213-5.

${ }^{9}$ Kobayasi T, Midtgard K, Asboe-Hansen G. Ultrastructure of human mast cell granules. $J$ Ultrastruct Res $1968 ; 23$ : 153-65.

${ }^{10}$ Hauge A, Staub N. Prevention of hypoxic vasoconstriction in the cat lung by histamine releasing agent $48 / 80$. J Appl Physiol 1969;26:693-9.

${ }^{11}$ Haas F, Bergofsky EH. Role of the mast cell in the pulmonary pressor response to hypoxia. J Clin Invest 1972; 51:3154-62.

${ }^{12}$ Bergofsky EH. Active control of the normal pulmonary circulation. In: Moser KM, ed. Pulmonary vascular diseases. New York: Marcel Dekker, 1979:233-77.

${ }_{13}$ Tucker A, McMurtry IF, Grover RF, Reeves JT. Attenuation of hypoxic pulmonary vasoconstriction by verapamil in intact dogs. Proc Soc Exp Biol Med 1976; $151: 611-4$.

${ }^{14}$ Howard P, Barer GR, Thompson B, Warren PM, Abbott CJ, Mungall IPF. Factors causing and reversing vasoconstriction in the unventilated lung. Respir Physiol 1975;24:325-45.

15 Bergofsky EH, Haas F, Porcelli RJ. Determination of the sensitive vascular sites from which hypoxia and hypercapnia elicit rises in pulmonary arterial pressure. Fed Proc 1968;27:1420-5.

16 Paintal AS. Impulses in vagal afferent fibres from specific pulmonary deflation receptors. The response of thes receptors to phenyl diguanide, potato starch, 5HT and nicotine and their role in respiratory and cardio-vasculer. reflexes. J Exp Physiol 1955;40:89-111.

${ }^{17}$ Fox B, Bull TB, Guz A. Innervation of alveolar walls in the human lung: an electronmicroscopic study. J Anat $1980 ; 131: 683-92$.

Requests for reprints to: Dr B Fox, Department of Histopathology, Charing Cross Hospital Medical School, $\overrightarrow{\vec{B}}$ Fulham Palace Road, London W6 8RF, England. 